\title{
Arundhati Roy's: The God of Small Things: As a Hybrid Linguistic Text
}

\author{
Shiva Zaheri Birgani \\ Department of English Language and Literature, Boroujerd Branch, Islamic Azad University, Boroujerd, Iran \\ Email address: \\ Shvzaheri@gmail.com \\ To cite this article: \\ Shiva Zaheri Birgani. Arundhati Roy's: The God of Small Things: As a Hybrid Linguistic Text. International Journal of Information and \\ Communication Sciences. Vol. 4, No. 2, 2019, pp. 35-45. doi: 10.11648/j.ijics.20190402.11
}

Received: May 7, 2019; Accepted: June 10, 2019; Published: June 25, 2019

\begin{abstract}
This study focuses Arundhati Roy's The God of Small Things (TGST). Roy is an Indian writer and activist in women's studies. She published her novel in 1997. It is semi-autobiographical and a major part captures her childhood experiences in Aymanam. The plot of the novel taken place in Ayemenem, in Kerala, an Indian state. Kerala is small India, because it is like India for having a complex and multicultural society. In the novel, Indian situations and characters are models for postcolonial outlook. India is a country which was colonized by British Empire at the end of the sixteenth century. This land had important benefit for Britain. This colonization affected Indian society, culture, and literature. The present researcher tried to analyze some postcolonial concepts. The novel challenged static notions of identity, specifically the construction of postcolonial women too. Roy as a hybrid diasporic woman tried to relate to gender and caste among other social concerns. She tried to express her own experience in her own voice. She used the Western language against colonialism itself. It is a kind of resistance. The present researcher tried to discuss the notion of hybridity and postcolonial resistance in TGST. This notion can be seen in several cases in the novel. Hybridity is a significant issue in the novel. Postcolonial resistance is an important issue in the novel. When Roy uses English language which it is a colonial language, she does a kind of resistance against colonization itself. Roy refers to the children's life and language as a means of resistance.
\end{abstract}

Keywords: Hybridity, Diaspora, Post Colonialism, Language, Resistance

\section{Introduction}

\subsection{Hybridity in Language}

Diaspora is an important issue which was significant in TGST. Diaspora has taken place in various layers of the Indian history. Diaspora has mostly taken place during migration and transition. Hybridity is unavoidable in diasporic communities such as, Kerala. Kerala was a complex and diasporic society. Hybridity refers to an inbetween space. Bhabha believes that the in-between space "allows for much diversity and flexibility in identity" [1]. There were biological, cultural and linguistic hybridity in $T G S T$. Lingubridity or hybrid linguistic identities has to be studied within specific societies.

Bhabha believes that in-between space "allows for much diversity and flexibility in identity" [1]. In postcolonial communities, the women have to make their own identity between both of two cultures. The present researcher believes that there is hybridity and in-between space in TGST. The novel challenges static notions of identity, specifically the construction of third world or postcolonial women. Indian women are located in terms of undeveloped, oppressive, highly illiterate and religious fanaticist. Not only the Indian society is affected by the Western culture, moreover this is affected by the Eastern culture such as, Islamic and Persian culture. The following sentence is an important significance for this claim: "My dearest Papa, Today Koh-i-noor vomited after lunch and is running a temperature" (13). Koh-i-noor refers to Islamic culture. This is a name for the girls. Roy tries to show a binary opposition between modern, educated, free, Western women, and oppressed, poor, traditionally bound Third World women. Roy as a hybrid diasporic woman tries to relate to gender and caste are among the social concerns. She tries to express her own experience in her own voice. Many postcolonial writers try to use the literary forms and techniques of the colonial power's own language, and so used allegory, disrupted narratives flow, 
magic realism, and irony, and so on to create alternative views of the colonial situation. Roy uses such tools against the colonization itself in her novel. For example, Christian allusions help to show a constant and ironic parallel between what should be and what actually is. The notion of hybridity can be seen in several cases in the novel. Hybridity is a significant issue in the novel. Postcolonial resistance is an important issue in the novel. When Roy uses English language which it is a colonial language, she does a kind of resistance against colonization itself. Roy refers to the children's life as a means of resistance. The present researcher believes that it may be seen as a kind of Orientalism in TGST.

TGST is a hybrid text. There is a linguistic context. There are native languages, dialects, songs in this context. This is a postcolonial identity. TGST is full of hybridity in terms of language too. "Linguistic examples include pidgin and creole languages, which are local versions of a language brought by colonizers" [2]. We could find the following samples for the linguistic hybridity: Arundhati Roy is an Indian writer, but she writes her novel in English. We can see frequently Malayalam words, poems or verses of songs. The writer tries to translate some of these words. We can give this example of these songs: "A song from the Onamboatrace filled the factory. 'Thaiythaiythakathaiythaiythome! Enda da korangacha, chandiitharathenjadu? (Hey Mr. Monkey man, why's your bum so red?'[2].

We could find the second suggestion in two parts of the novel, Roy writes some words in an inverted form. The example for inverted words is when she writes "nataSniriehtseye" (Satan in their eyes) (181). This sentence shows Ammu's belief about the twins. And the example for inverted sentence is "Ot pots niartllupniahc" (To Stop Train Pull Chain) (193). This sentence is from Estha's tongue. Why did Roy write in the inverted form? Roy tries to define subalternity and the marginality by the linguistic originality an inventiveness. Having two state languages would have fatal consequences for the country's geopolitical future. "Inglish" (32). Shows the voice of hybrid Indian citizens that "grew up being subject to the influence of two or more languages, being English one of them. (Agustin Reyes Torres). This reflects that Indians use the English language, but they behave in Indian forms, concepts and experiences. Sometimes the characters do not speak English and cannot understand the other characters. One of these characters is Kochu Maria. This is showing in this sentence of the novel: "Estha would rise from the dead, stand on his bed and say, 'Et tu? Kochu Maria? - Then fall Estha!' and die again" (40). Kochu Maria was sure that Ettu was an obscenity in English and was waiting for a suitable opportunity to complain about Estha to Mammachi. Sometimes the characters speak English, but do not know what they are saying. They have learned to pronounce a word, but it has no meaning for them. A good example for this situation is when Comrade Pillai's son, Lenin, cites Shakespeare: "lend me yawYERS" (129). Sometimes words are written as the twins imagine them: "They had to form the words properly, and be particularly careful about their pronunciation. Prer NUN sea aysun" (18). This shows they play with English words easily.

Let's return to Sophie Mol again. She is discussed as a real hybrid. The word of SophiMol is the mixture of English and Malayian words. Indians adapted English to their linguistic needs. This linguistic practice in the Indian society may create the conditions for the development of a new, Indian version of English. Although she is a hybrid of EnglishIndian, she had lived in English and is trained in English culture. And she is known as an English daughter in Ayemenem. We can see this in the part of the novel when Roy writes: "It was about nine in the morning when Mammachi and Baby got news of a white child's body found floating downriver where the Meenachal broadens as it approaches the backwaters" (119). We know the color of white body refers to being English Sophie Mols, because her Indian heritage is not mentioned. Sophie Mol tries to be friend with the twins, but they escape. "Sophie Mol put the presents into her go-go bag, and went forth into the world. To drive a hard bargain. To negotiate a friendship" (126). This part of the novel shows that Sophie Mol acts as a cultural hybrid. Because when she gives the twins the presents, she tries to adapt to her cousins. Although she is trained in English, she wants to be with them. This shows she tends to her half Indian.

SophiMol is a word which is composed of two parts; Sophi and Mol. This word is mixing of English and Malayalam that indicates Kerala's multiple local linguistic cross-currents. Roy uses words from India's state language into her English novel. And he accepts the role of interpreter for nonMalayalam-speaking readers when she explains words: "In Malayalam, Mol is Little Girl and Mon is Little Boy" (29). This is an example for hybridity in the novel. Sometimes Roy protects the power relations of this cultural mediation, when she refuses to explain: "Estha and Rahel couldn't call [Chacko] Chacken because when they did, he called them Chetan and Cheduthi. If they called him Ammavan he called them Appoi and Ammai [...] so they called him Chacko" (TGST 18). Roy tries to emphasize in names and naming for constructing meaning and identity. This quotation estranges her "non-Malayalam readers" and shows that "cultural differences cannot always be easily translated or explained [3]. They are English in taste, but they are Indian in blood.

In TGST, the concept of hybridity is revealed in its simple sense, i.e. a blending of two cultures and in the interest of individual progressive thinking and social justice. In fact, conservative Hindu spreading that set up monolithic cultures has disturbing implications for Indian women who have a stake in challenging patriarchal/traditional Indian behavior and thinking.

The woman has an in-between space in the postcolonial debate which "allows for much diversity and flexibility in identity" [4]. Criticism of colonialism on an ideological basis and the stress on the colonizer / colonized dichotomy exclude hybrid groups. But, hybrid groups that developed as an impact of colonialism represent a fundamental sign of domination and exploitation. These women have to create 
their own identity between both of two cultures. Racial hybridity is extremely important since they do not define themselves as either Anglo or Indian solely. They resist complete identification with the Indian and the British and claim their own space and subjectivity. They have a generous space of culturally within which they can operate as individuals. The in-between spaces lead to "new signs of identity and innovative sights of collaboration and contestation in the act of defining the idea of society itself' [5].

\subsection{Postcolonial Resistance in the Novel}

Resistance takes place in colonialist relations of postcolonial theory. It has taken in many forms, from the nineteenth-century parody of Macaulay's 1835 "Minute", to Tiffin's literary responses [6].

There is "a Copernic change" in the relationship between "Western culture and the empire" [7]. This change took place in two earlier ones: the European Renaissance rediscover Greece during its humanistic period, and "the Oriental Renaissance, when the cultural riches of India, China, Japan, Persia, and Islam were firmly deposited at the heart of European culture". The second refers to "what Schwab calls Europe's magnificent appropriation of the Orient" (195). It is significant in "the history of the human adventure"[7]. This involves "the discoveries of Sanskrit by German and French poets and artists, of Persian imagery and Sufi philosophy by many European and even American thinkers from Goethe to Emerson".

There are two periods of resistance. The first is the period of "primary resistance which literally fighting outside intrusion, and the second is the period of ideological resistance which tries to the sense and fact of community against all the pressures of the colonial system" [7]. Resistance is "the struggle between colonizer and colonial" [7]. The struggle includes different forms such as, "strikes, marches, violent attack, retribution and counter-retribution" (219).

There are "three great topics in decolonizing cultural resistance" (215). The first one refers to "the resistance on the right to see the community's history whole, coherently, integrally". The concept of the national language is central, and national culture organizes and sustains communal memory. Anderson argues that "creole communities redefined these populations as fellow nationals in Spanish America". The second one refers to "a reaction to imperialism, which it is an alternative way of conceiving human history". This alternative "is based on breaking down the barriers between cultures". The third one refers to "a more integrative view of human community and human liberation" from separatist nationalism [7].

Imperialism relies on the large scope in the colonies. The colonies were affected by "a culture giving empire ideological attitudes" (222). Said believes that nationalism signifies all sorts of undifferentiated things, and identifies "the mobilizing force that coalesced into resistance against an alien and occupying empire on the part of peoples possessing a common history, religion, and language" (223). Nationalism was rooted in "the long-standing struggle for native rights and independence by Congress in India" (224). "Cultural resistance to imperialism has often taken the form of what we can call nativism used as a private refuge" (275). "The hero of Algerian resistance, Emir Abdel Kader, in the nineteenth century" is an example for this resistance.

Many postcolonial writers have employed the literary forms and techniques of the colonial power's own language, and so used allegory, disrupted narrative flow, magic realism, irony, and so on to create alternative views of the colonial situation. This appropriation demonstrates the ability of postcolonial writers to use the tools of metropolitan language against itself. These literary techniques are self-consciously used to demonstrate alternative and oppositional ideological principles. Roy exemplifies this appropriation in her Booker Prize- winning novel The God of Small Things. For example, Velutha is like Christ. He was a carpenter who suffered the little children to come unto him. Both, Christ and Velutha, were sacrificed for a greater cause. Christ was for the salvation of humanity, and Velutha wants to salvage the stratified social order and keeps an upper-caste family name intact. "Biblical Christian allusions help to show a constant and ironic parallel between what should be and what actually is" [8].

Edward Said stated that postcolonial writing-literary and theoretical - is a form of resistance to highly dubious Western construction of "Orient" in his foundational text of postcolonial criticism, Orientalism. Postcolonial literary studies focus on what happens when the formerly colonized culture starts to produce its own knowledge about itself. The discourses that create the colonizers as the knowers and the colonized as the subjects of knowledge all depend on our old friend, the structure of binary oppositions, including West/East, Occident/Orient, civilized/native, self/other, etc. when "the empire writes back", these binary oppositions are deconstructed; when a colonized subject insists on taking up the position of "self", as the creator of knowledge about his or her own culture, rather than as the subject of that knowledge, these binary oppositions start to fall apart The present researcher believes that when Roy uses English language, she does a kind of resistance against colonization. Roy also employs a disjointed, nonsequential narrative that echoes the process of memory, especially the resurfacing of a previously suppressed, painful memory. Roy rises from the level of personal and folk experience. She uses ancient figure such as, kathakali dance for a kind of resistance against British imperialism. Returning to the old principles represents their identity and it is a kind of resistance to colonialism. They want to show they have their identity themselves.

As the children attempt to form their own identities, naming and renaming themselves in the process, Roy places in parallel the effect of the process, by intertwining the past and the present. Similarly, this process echoes the progression of the Indian people, like all other cultures that attempt to find ways to maintain their traditions within a time 
of increasing globalization. The postcolonial writers try to form their identity by using the children's characters. The children use and repeat these phrases throughout the story so that the phrases themselves gain independence and new representational meanings in subsequent uses. Roy's most original contribution in this novel is her portrayal of children, entering into their thinking in a way which does not sentimentalize them but reveals the fierce passions and terrors which course through them and almost destroy them. Also the children imitate their adults and want to find independence. The postcolonial writers as well imitate the colonizers for forming their identities. Indeed, the perspectives of child protagonists Rahel and Estha are given the most weight of any throughout the novel. Even though Rahel and Estha are victims of circumstance, they are to an equal extent intelligent evaluators of it. Although the book has no single protagonist and no definitive moral, it certainly champions details of life to which contemporary society tends to be too frenzied or farsighted to pay heed. Roy does her best in the novel (as well as in her other writing and political activism) to enfranchise the "Small Things", overlooked people and issues that, in her opinion, deserve more attention (153).

\section{Method}

The present researcher tries to analyze the novel based on some postcolonial concepts. Hybridity is based on White who believes that history is the title of scientific discipline in the nineteenth century. In postcolonial regions, there is migration and transition of the different nations always. In the result of this transition of the peoples, the new identities had been made .This condition creates transcultural identity. Hybridity became significant concept in postcolonial studies. The present researcher tries to work on diaspora and hybridity from Bhabha's view. The writer and the character of Ammu are women. And they belong to diasporic community, the researcher wants to work on the role of women in Indian society. Other concepts are resistance and orientalism. Said worked on the two last concepts. The process of the world shrinking and becoming a single place refers to globalization. This happens in complex society. India tries to inject foreign investment for globalization.

\subsection{The Relation Between the Role of Woman and Postcolonial Literature in India}

Loomba, in her book Colonialism/Postcolonialism, believes that anti-colonial or nationalist movements have tried to show the image of the Nation-as-Mother to make their own ancestors "and also to control the activity of women within the imagined community. These movements encourage women to create 'sons who may live and die for the nation" (180). The nation is shaped as a home, and its leaders are like paternal roles and fellow-citizens are brothers and sisters. For example, "the King was a Father to his people" (i81). The family and the State completed each other. In colonialism, the family becomes the symbol of anti- colonial movement because it indicates inner space (182). When appropriated families of colonized subjects in colonial situation and intrusions were imagined, "the family will be symbol of resistance" [8].

In addition, Loomba states that the repressed peoples make anti-colonial nationalism to represent a selfhood during colonial rule. The image of nation as a mother indicates both female power and female helplessness. "This mother" defends her son against colonial pillages, but is also herself devastated by colonialism and she "needs her son's protection" (182). The Indian nationalist, Sri Aurobindo writes "I know my country as Mother. I offer her my devotions, my worship". Women must be educated because "educated women will be better wives and mothers", not to usurp authority from men. In Renaissance Europe, humanist writings pictured "women as assistant to their men". For example, Sir Thomas More defended female education. The colonialists offer education to reform women's status, and nationalists make a parallel process of education and reform for them (women) (183).

Here, the ideal woman is in opposition to the memsahib. The ideal woman is drawn by brahminical notions of female self-sacrifice and devotion. When an ideal gentlewoman is constructed, this woman is separated from their lower- class sisters, who are servants or sources of folk or popular music and tales, dramas and wit. In this condition, many forms of women's popular culture are marginalized. These forms expressed difficulty of women "in male-dominated society or sexual desire using powerful humour, sharp". Women are half the population of any nation. Even we know little or nothing about the "widows themselves and of the fact of their pain" (185). The discussions around these "widows" have a striking place within postcolonial theory because they "are the agency of the colonized". The women's voices become absent in the immolation discussion. This absence shows the "intermixed violence of colonialism and of patriarchy". Women are "real targets of colonialist ad nationalist discourses".

According to Loomba, in her book Colonialism/Postcolonialism, there are "some writings of women for eminent scholars" (186). These writings worked a long side, within or in opposition to the nationalist and anticolonial notions. The more feminist study retrieves the lives of women under colonial rule, and it shows "women as individuals as a potential collectivity" (186). They were the target of earlier patriarchal rewritings of tradition. Anticolonial struggles are different in their attitudes to "female agency and women's rights". Ghandhi has non-co-operation movement. It is called "proto feminist" (187). Gandhi ignored women's fighting, and followed "the conceptions of the family and society". In India, women's fighting confronted strong political interaction. In the nineteenth century, "women" were not in "any public anti-colonial protests". The terms shaped at that time caused to make "the nationalist movement from 1920s onwards". Women's roles were expansion of "their household roles-caring", "subservient", "and nonmilitant". 
There were some attempts "to restrict their agency". Moreover, women had various responses against these attempts. Many women were active in colonial struggles. These women were not feminist; they did not see tension between their own struggles and those of their community at large. They worked outside purely household spaces, some women were leadership. These women explained new conceptual spaces for women. They went "into public spaces in the name of motherhood and family". In addition, Loomba mentions that:

Women continue their struggles for equality after formal independence and describe the nature of postcoloniality. Anti-nationalisms legitimized women's public activity. Postcolonial countries more easily admit women's participation in politics than metropolitan ones because of this nationalist legacy. In recent years, there has been an effort to exploit women's political activity and even religious fundamentalism. The Hindu, Islamic or Christian right-wing movements are taken place by active women in the different parts of the world. Women used trickily the question of religion. "It has surfaced as a major factor in women's relationship to the nation and to postcolonial politics". Many postcolonial systems repressed women's rights, and used religion to reinforce their subordination. The Islamicisation of civil society constructed national identity in Pakistan, Bangladesh, Afghanistan, and Saudi Arabia. Religion has a key role 'in mutations of postcolonial identities and gender roles. Islam is understood as more prone fundamentalist appropriation than any other religion'. In India, women like Sadhvi Rithambara and Uma Bharati are key players for Hindu nationalism by entreating fears of Muslim fierceness'. 'Women are objects as well as subjects of fundamentalist discourses. The relationship between women, nation and community is variable, both in the colonial period and afterwards. Colonial and anti-colonial histories complicate feminism. Women tried to struggle for self-determination, democracy, anti-imperialism and re-shaped their understanding of themselves. Amerita Base suggests that women had participated in nationalist struggles in contemporary period. (189)

A national feminist conference was been disposed in 1987, 79 percent of the members were active in black, labour, working- class, church, and other political movements. Women are known with more anti-imperialist or workingclass than with the concerns of white First world feminism. The women's movements have been divided according to class, colour, religion, location, sexuality and politics. Black women in the USA may have the politics of white feminism, but the independent feminists regard the issues of sexuality and fierceness in India. "Nationalist or class-based movements" have subordinated questions of "women's sexuality or autonomy" (190).

In India, women's movements try to pay to the questions of sexual and household fierceness and also of equal pay for equal work. Totally, postcolonial women's movements have fought 'against state repression rape, racism, patriarchy, or better working conditions and for choice of sexual direction'.
Postcolonial women's movements have tried to defy the assumption that they are inspired by its Western counterparts. These movements follow their local and native roots. They re-wrote local histories, pro-colonial symbols and mythologies, and express their voice. Today, these movements have to debate "the dynamics of globalization", and "the postcolonial nation-state" (191).

In addition, Loomba mentions that earlier women's labour directly or indirectly enforced the colonial machine. "Globalization" often reproduces "the general effects of colonialism". These women's labours are now experimented by medical experiments, and there are "the receivers of drugs and contraceptives banned in the West" (192). Fundamentalists believe that Western or imperialist forces are "responsible for all manner of evil, such as women's repressions" (192). But globalizations make an "international women's development network". The governmental or feminist organizations try "to improve women's health", or "working conditions", also "moving enlightenment from the West to the rest of the world" (192). "Global imbalances profoundly structure feminist agendas in the postcolonial world". In postcolonial communities, women have attended fully postcolonial politics, "from the established forms of political action to the new social movement such as, environmental programmers".

\subsection{The Effect of Colonization in Indian Society, Culture, Literature}

The relationship between literature and colonialism has motivated serious reconsiderations of each of these terms. Since Plato, literature is intervenes between the real and the imaginary. According to Loomba in her book Colonialism/ Postcolonialim), literary texts distribute in society because they are part of other institutions such as the market, or the education system (63). They play a crucial role in "constructing a cultural authority for colonizers", both in the metropolis and in the colonies. "Transculturation" happens in literature. Both sides of the colonial and aspects of the "other" culture are reflected in literature. Literature "creates new genres, ideas and identities" (64).

Some writers or poets use colonialist concerns in their writings. For example, John Donne separates the lovers' private space from the fast expanding outer world in his poems. Donne describes the female body in terms of the new geography in his "Love's Progress". The lover/colonist tours her body/the globe to reach her "India". In "To his Mistris going to Bed", Donne uses the terms of the colonialist's interaction with the lands they "discover". Donne resembles sexual relationships to colonial relationships. He believed that a male lover, like a European discoverer, who discovers other lands, discovers the female body. And the sexual promise of the female body is like the colonies' wealth believes that Said's Orientalism expresses "literature as a part of the creation of colonial authority".

Loomba, in her book Colonialism/Postcolonialim (1998), maintains literary texts can oppose dominant ideologies (67). Moreover, literature both reflects and creates modes of 
expression that are central to the colonial process. Plays such as Othello and The Tempest focus on colonialist ways of seeing and have inspired anti-colonial and anti-racist movements and literature. There are cross-cultural interactions and hybridities in literature. There are the European well-suited of non-European texts and traditions, especially Arabic texts, throughout the medieval and early modern periods. Literary texts help us towards "an analysis of colonial history" (67).

Jenny Sharpe, in her book Allegories of Empire: The Figure of Woman in the Colonial Text, says that a rebel expanded from the sepoys of the army in 1857 (67). It included local rulers as well as peasants. It is the First War of Indian Independence. It is what British called "The Mutiny" of 1857. It began the renewal as an existing colonial stereotype. It includes the "mild Hindoo" and the savage rapist of British women. There are no stories of rape before this rebellion. After this event, men and women wrote the reports, memories and other Mutiny narratives. Sharpe explains what she calls "the truth effects" of stories about white women's infringement and damage. She suggests that 'fear-provoking stories have the same effect as an actual rape; they violently reproduce gender roles in the demonstration that "women's bodies can be sexually appropriated". She debates that these rape stories shake British administration. But it secures its authority and project itself as part of a civilizing mission. "A crisis in British authority is managed through circulation of the violated bodies of English women as a sign for the violation of colonialism" (4). Because of this history many of the English novels were written about India: E. M. Forster wrote $A$ Passage to India. This novel is about an Indian man, wrongly of raping a British woman. Sharpe, in his book Allegories of Empire: The Figure of Woman in the Colonial Text, maintains that this story recalls the same "racial memory that echoes across the Mutiny novels as a horrific nightmare" (123). This history affected many writers. They wrote many novels about India. The British murdered hundreds of defenseless Indians in the 1920s. In this novel, raping is a metaphor for imperialism, and an Indian man is in turn abused by the colonial machinery. It was written during the nationalist struggles. These two books were written at the time of the crisis of the colonial authority. The writer wants to confirm the moral value of colonization.

Spivak believes that nineteenth-century British literature showed that imperialism was an important part of the cultural representation of England to the English. We cannot find unpleasant colonial details in Victorian novels. Loomba in her book Colonialism/Postcolonialism, states "the colonies are not marginal in all European literature, [...] an obsession which resulted in bestsellers such as G. A. Henty's novels for young adult (With Clive in India or With Wolf in Canada), Rider Haggard's adventure stories on Kipling's fictions" (73). Spivak suggests that the drama of imperialism inflected feminist individualism in the nineteenth century. And it "marginalized the native woman" and "defended the white woman who spoke and acted about that subject".
There is another aspect of the relation between literature and colonialism. It refers to dominant critical views, which sanctified within educational systems. According to Loomba in her book Colonialism/Postcolonialism, in fact, Britain changed literary study to 'discipline' of study in Britain universities for colonial administrators instructed in Western literature (76). Thomas Babington Macauly architected English education in India. He wrote "Minute on Indian Education"[9]. He believes that natives should be "English in taste, in opinion, in morals, and in intellect". The natives were attempting Western values through literary texts, and European culture were constructed as superior of human values. For example, "the plays such as Shakespeare's Othello worked in all over the world-in Britain, in South Africa and in India, It worked to increase the culture authority, for 'Englishness', not just Shakespeare" ( 74). "English literary studies became a mask for economic and material exploitation, and were an effective form of political control" (76). Loomba suggests:

Certain humanistic function traditionally associated with literature- for example, the shaping of character or the development of the aesthetic sense or the disciplines of ethical thinking- were considered essential to the processes of sociopolitical control by the guardians of the same tradition.

Many Indians themselves wanted to learn English education. They were reformers and nationalists who were opposed to British rule in India. British educational policy was shaped by local politics, and was not simply exported from England. Some local works, like literary texts of India, were written. Orientalists defended such "local works were seen as property of a venerable ancient past in India".

Bhabha, in his book The Location of Culture, suggests that there is 'hybrid' and 'ambivalent' in colonial authority, when it is imitated or reproduced (38). And it makes "spaces for the colonized to subvert the master-discourse". When we want to debate about colonial identities, it is best we study literature in the colonies. According to Loomba in her book Colonialism/Postcoloinalism, all Western books, religious like the Bible to heathen, or literary like Shakespeare to uncultured, are to increase English (European) authority (culture) (77).

Benedict Anderson, in his book Imagined Communities, states that in 1813, Parliament mandated the allocation of 100,000 rupees a year for the promotion of native education, both "Oriental" and "Western" (90). In 1823, a Committee of Public Instruction was set up in Bengal; and in 1834, Thomas Babington Macaulay became president of this committee. English educational system would create "a class of persons, Indian in blood and color, but English in taste, in opinion, in morals and in intellect" [10]. In 1932, "Bipin Chandra Pal" said that "the India-born Civilian" was "as much an Englishman as any Englishman in mind and manners" (92). $\mathrm{He}$ was as much a stranger in his own native land as the European residents in the country.

According to Loomba, in her book Colonialism/Postcoloinalism, in India, "the early nationalists were trained English education", and then they "used English 
literature to argue for independence" (79). English literature like Shakespeare, and English education nourished the ideas of freedom in the native people. This event also happened in Africans. We can point out these sentences in Shakespeare's Caliban, who tells Prospero and Miranda: "You gave me language, and my profit on't/ Is, I know how to curse. The red-plague rid you/ For learning me your me your language!".

Dr. Dilip K. Chakravorty, in his book India in English Fiction, believes that "during the British regime quite a large number of British writers living in India" (90). Some of them wrote historical novels, because they became interested in certain "aspects of the history of India" These novels give us an idea of the respective author's understanding and appreciation of Indian history. There were "some Indian authors also who wrote such novels and some of them proved quite popular" (91). One such historical romance was named "Baladitym written by Mr. P. Ayyar, I. C. S.". The novel, "published in 1930, has as its theme the overthrow of Kanishka's Empire by the Huns". Incidentally, this seems to be the only notable novel in English having the Hindu period as its background. Moreover, Chakravorty says that "the first organized struggle of independence of India produced a large number of novels in English" (92). Certain interesting aspects of these novels may briefly be mentioned. Most of the novelists preferred to express what they considered to be "their righteous wrath against the leaders and participants of the Mutiny". Some writers liked to take a different position in this respect. The writer has sympathetic consideration for those whom he considers "weak-kneed people" "misled much against their will" [11].

In addition, Chakravorty mentions that "the struggle of independence in India does not find a deserving place in these novels" (95). Some of "the British novelists" living in India during British rule were adequately conscious of "the growing political unrest among the Indians" and this consciousness found proper and adequate expression in some of the novels written by them. "Some of the English writers of fiction" were fanatically against the political aspirations of the people of India, but most of them "lacked sympathy and understanding for the Indian point of view".

\section{Literature Review}

In Commonwealth Literature in English, Dr. Amar Nath Prasad considered a study in TGST's theme and technique. Ronald Bogue wrote and essay about childhood and becoming-untouchable in TGST. This essay was printed in Deleuzian Fabulation and the Scars of History. Scot Trundell is and independent scholar with a bachelor's degree in English literature. He wrote an essay about the significance of the sexual encounters between Rahel and Estha, and Ammu and Velutha.

Joyce Hart is a writer who he studied Roy's poetic language and unique writing style. Laura Carter is a freelance writer. She considered the social malaise present in Roy's version of conemporary Indian society as a function of
Western influence. Douglas Dupler is a writer and a teacher who examined the relationship between individuals and the cultural forces acting upon them within the novel. Ritu Menon believed that TGST is about childhood and the loss of innocence. Two French critics, Carole Durix and Jean-Pierre Durix, examined TGST from psychoanalytic, post-structural and postmodern perspectives .Also, R .K .Dhawan examined this novel from gender issues, transgression and linguistic aspects .In the field of postcolonial studies, Dhawan organized a study about history. Here, the focus will be mostly history, diaspora, hybridity, and postcolonial resistance, the role of women in Indian society, globalization and orientalism.

\section{Discussion}

These are outlined in separated items, such as the notion of hybridity, the role of women in Indian society, globalization, postcolonial resistance and Orientalism in TGST. The notion of hybridity is one of the items. The present researcher believes that this notion can be seen in several cases in the novel. Hybridity is a significant issue in the novel. Another issue is the role women in Indian society, because there are several female characters, such as Ammu, Rahel, and so on in TGST.

Economic growth causes change in Ayemenem. It becomes a globalized community. Postcolonial resistance is an important issue in the novel. When Roy uses English language which it is a colonial language, she does a kind of resistance against colonization itself. Roy refers to the children's life as a means of resistance. The present researcher believes that it may be seen as a kind of Orientalism in TGST. The results are given in a final item, the conclusion.

\subsection{TGST and the Role of Women in Indian Society}

Roy dares to cross the boundaries of caste to face the most hideous form of ostracisation and stands on the fringes of Indian society. Indian society does not provide any satisfactory choice to women who stand apart from the usual pattern of accommodation to wifehood and integration into the in-laws. Thus, transgression is regarded by patriarchy not enough powerful to disrupt the natural established order, though to some extent, particular individual actions affect social reactions, and exclusion/death remain specifically the ultimate punishments. Yet, the philosophy of Hindu women, i.e. passive resistance is disturbing. On the one hand, this supposes that women have no choice, although Western interpretations challenge this deeply socio-religious rooted myth. Western women are to free Indian women from such typecasting and promote more direct actions. Certainly, moral superiority is a myth that could keep women stranger to themselves, judges of other women if not fearful or contemptuous towards their male counterparts. Indeed, Indian women could experience a vast array of human emotions and actions beyond defined Indian traditional women roles. 
A woman protagonist leads a life in complete conflict with traditional values. The novel implies the traditional ways of life are changing and women are starting to think in a different way. It is deconstructing stereotyped representations of some aspects of Indian family life and culture which shape it, i.e. a rigid interpretation of the Sacred Book (The Vedas), established sexist prejudice, a tight family budget in a society that still privileges dowry and the belief that a Hindu woman belongs to her husband's family. Through the process of construction and deconstruction of the woman protagonist, the novel demonstrates the power of literature to create awareness and sensitivity of the struggles that the main woman character faces are the result of the changing times, notably the inner workings of her minds, her personal perplexities and social confrontations as individual growing into themselves. We can see this matter in this part of the novel in which Amm's brother, Chacko, decided about Ammu's relationship with Velutha.

In $T G S T$, the primary purpose is the isolation of the individual soul, particularly of woman, and the secondary purpose is the political considerations. The novel seeks to define the many voices of the previously marginalized other and establish a claim to woman cultural identity. Woman's selfhood has been subordinated, diminished when it has not been outrightly denied. An important step in recognizing the interconnections between the local (India) with the global (diasporic) is exploding cultural stereotypes that determine a self in terms of other by locating India on the opposite side of the tradition vs. modernity dichotomy.

In $T G S T$, the concept of hybridity is revealed in its simple sense, i.e. a blending of two cultures and in the interest of individual progressive thinking and social justice. In fact, conservative Hindu spreading that set up monolithic cultures has disturbing implications for Indian women who have a stake in challenging patriarchal/traditional Indian behavior and thinking.

The woman has an in-between space in the postcolonial debate which "allows for much diversity and flexibility in identity" [12]. Criticism of colonialism on an ideological basis and the stress on the colonizer / colonized dichotomy exclude hybrid groups. But, hybrid groups that developed as an impact of colonialism represent a fundamental sign of domination and exploitation. These women have to create their own identity between both of two cultures. Racial hybridity is extremely important since they do not define themselves as either Anglo or Indian solely. They resist complete identification with the Indian and the British and claim their own space and subjectivity. They have a generous space of culturality within which they can operate as individuals. The in-between spaces lead to "new signs of identity and innovative sights of collaboration and contestation in the act of defining the idea of society itself" [13].

$T G S T$ challenges static notions of identity, specifically the construction of third world or post-colonial women. Indian women are located in terms of underdeveloped, oppressive, highly illiterate and religious fanaticist. Postcolonial Indian writer, as feminist argues that she needs to engage critically with the historically specific and dynamic location of women in India so as to a participate in cultural reproductions that reduce women's lives to a particular fixed patriarchal pattern and to avoid over creating binary appositions between modern, educated, free, Western women, and oppressed, poor, traditionally bound third world women. In an attempt to reclaim and write against the representation of third world women as the eroticized other, Roy serves political aims by writing against patriarchy. Yet she writes in the context of a society/community whose members do not have the luxury skills to read and write but are nevertheless the ones who represent and speak for these women.

Roy's novel based in India which the cross-cultural undercurrents are spanning continents, gives a new vision of Indian women, pleasing to Western mind and feelings and yet, reflecting partly Indian woman to come to terms with herself, a process which would certainly have not been affected within the particular socio-cultural location. In the novel, Indian women who resisted Hindu traditions are accused of transgressing and violating the oppressive patriarchal patterns within Indian family structure and therefore are condemned to ostracisation up to death.

As to the postcolonial diaspora, it is not solely immigration into Great Britain or elsewhere from other countries, but it is indeed a constant reminder that pre-colonized subjects are in the colonizers' land because they were in their own homeland. The specific phenomenon of immigration transgresses Western British sense of fixed boundaries and challenges the cultural identity of the White Englishman/woman as being homogeneous. It is perceived probably as threat to British national cohesion. The choice of Indian diasporic women is not only colonization in reverse and the voice of the other, but also the voice of hybridity. This diasporic novel struggles with patriarchy. Diasporic women need not solely define themselves in terms of their difference from mainstream of their countries of birth, but there is also this urge to differentiate from the country that lies behind them. This crucial need to escape, takes place in the context of differentiating and making a space for the Indian woman writer. It is especially the presence of various contradictory and sophisticated ideologies within the diasporic communities that renders Indian women's works so fruitful for queries of women identity and existence at a micro level from steady examinations of family life and negotiations to the ideological religious imperatives that features Roy's novel.

The novel represents the life of an Indian woman rethinking and reconstructing her identity. Each woman feels marginalized in her own socio-cultural location and ultimately tries to locate herself in the central position. The legacy of British colonialism has meant that Indian women now live outside their native land with different perspectives on postcolonial issues, raising specific voices which are powerfully articulated in their own defense.

Indeed, postcolonial Indian women novel emerged as a process that gathered space as political independence was 
acquired and cultural decolonization intensifies. Given that writing in English by women has developed greatly for obvious historical reasons, Indian women writing could be described as writing back to the dominant English as a quest for the establishment of woman cultural authority English serves as an ideological purpose and propagates Western culture among the colonized. But, Indian women writer has illustrated the power by which language with its signification of authority has been wrested from the dominant cultural. Roy is writing from positions between or across cultures and revalorizing marginalized cultural women identities. The construction/deconstruction of hybrid diasporic women identity related to gender and caste are among the social concerns shaping the work of the writer.

This powerful written testimonial mirrors the power of writing and literacy to free women's lives from the chains of a restrictive real-life milieu. The writer is speaking of her own experience in her own voice. She finds it hard to set up a balance between her femininity and autonomy, her Hindu traditions and Western modernity. She is both as woman and as racially different, into the receiving/ host society, her writing reflects certainly her disagreement with the officially accepted construction of correct behavior, aware of the problems of traditionally structured disadvantages.

Roy criticizes traditional networks which remain active in India to repress women's ideas, impulses and feelings in conscious and unconscious ways. Her writing in English is undoubtedly an inward thought as well as a personal release from Indian socio-cultural and political boundaries though shared by Indian feminist writers.

A woman writer highly criticizes certain kinds of women within a text. For example, the most evil figure in TGST is an older woman, the spinster aunt. She is absolutely malevolent, almost monstrous in her malevolence, and it is she who triggers most of the disasters that occur. Sometimes a woman writer tries to suppose to say good things about women. Roy is very good at showing the ways in which women of all classes and all generations are positioned by socio-cultural systems. Even this aunt, Baby Kochamma, is very much embittered as a consequence of her own history, and we are shown precisely how she has grown to be the way she is; not that it excuses her horrible actions, but Roy gives you a very complex picture of the dynamics that interplay between cultural constraints and individual choice.

\subsection{TGST and Globalization}

This term has had a meteoric rise since the mid-1980s, before which time words such as 'international' and 'international relations' had been preferred. The term 'international' rose in the eighteenth century. It referred to "the growing importance of territorial states in organizing social relations" [14]. Globalization is the process of becoming a single place. "In the 1980 s, it was dominated by sociology and political economy, but during the 1990s, it was associated postcolonial studies". It was suggested by Simon Gikandi. It involved a range of terms such as hybridity, transculturalism, "Third Space" (38). It is as "cultural imperialism" or "neo-imperialism" [14]. It is used to analyze "hybridization", "diffusion", "relativization", and interrelationship of global societies.

Globalization is important at two directions. The first refers to "the structure of world power relations", which is as a legacy of Western imperialism in the twentieth century. The second refers to "the ways in which local communities engage the forces of globalization bear some resemblance to the ways in which colonized".

Societies have historically engaged and appropriated the forces of imperial dominance. Local communities and marginal groups can both empower themselves and influence those global systems. In a global system, one may get free from local forms of dominance and oppression and also form a different kind of identity. International capital makes the new forms of control and also causes a continuity of oppression. Actually, their work is as "an intersection of colonialism, neo-colonial forms of power and the institutions of global control of more recent times" (462).

In TGST, "Roy opposes globalization and industrial development" [15]. This opposition derived from the Naxalites. When "the agricultural modernization" developed fertilizers and high-yield grain to India's farmers "in the 1960s (This is named Green Revolution by Indira Gandhi)", the peasant of the Naxalites faced greater impoverishment. "By increasing crop productions India can escape from the widespread famine, but the Green Revolution was never a total success". This process forced small producers into a dependency on fertilizers and pesticides, even dependency in "rice and wheat".

Roy believes that "agricultural modernization" plans deprived "India's most vulnerable rural communities in the name of development". She says that this Western plan shows a deep lack of imagination. "In the early of 1990s", India attended outside investment as "part of its economic liberalization". This plan impoverished its own citizens and caused a corruption deals with global multinationals. Ayemenem is a small town which received economic growth between the two time schemes of the novel. "It changes and becomes globalized". Its residents find they can make money by working "unhappily". But on the other side, the poverty increased. "New wealth", "increased poverty" and "tourism and satellite television" are seen as paradoxical issues in Ayemenem as a globalized community.

Roy believes that "globalization increased social inequalities in India" (35). These inequalities are made "in several ways". Disparities are "widening in social opportunities", "the divide between rural and urban India" are sharply increasing. Thus differences in "wealth between regions" are increasing. Roy believes that India's future depends on its plurality and its political alternatives are local:

India's redemption lies in the inherent anarchy and fractiousness of its people and its political formations [...] Corporatizing India is like trying to impose and iron grid on a heaving ocean, forcing it to behave. My guess is that India will not behave. It cannot. It's too diverse, too grand, into believing in one single idea, which is, eventually, what 
corporate globalization really is: Life is Profit.

\subsection{Postcolonial Resistance in the Novel}

Resistance takes place in colonialist relations of postcolonial theory. It has taken in many forms, from the nineteenth-century parody of Macaulay's 1835 "Minute", to Tiffin's literary responses (93).

There is "a Copernic change" in the relationship between "Western culture and the empire" [16].

This change took place in two earlier ones: the European Renaissance rediscover Greece during its humanistic period, and "the Oriental Renaissance, when the cultural riches of India, China, Japan, Persia, and Islam were firmly deposited at the heart of European culture". The second refers to "what Schwab calls Europe's magnificent appropriation of the Orient" (195). It is significant in "the history of the human adventure". This involves "the discoveries of Sanskrit by German and French poets and artists, of Persian imagery and Sufi philosophy by many European and even American thinkers from Goethe to Emerson".

There are two periods of resistance. The first is the period of "primary resistance which literally fighting outside intrusion, and the second is the period of ideological resistance which tries to the sense and fact of community against all the pressures of the colonial system" (209). Resistance is "the struggle between colonizer and colonial" (210). The struggle includes different forms such as, "strikes, marches, violent attack, retribution and counter-retribution" (219).

There are "three great topics in decolonizing cultural resistance" (215). The first one refers to "the resistance on the right to see the community's history whole, coherently, integrally". The concept of the national language is central, and national culture organizes and sustains communal memory. Anderson argues that "creole communities redefined these populations as fellow nationals in Spanish America". The second one refers to "a reaction to imperialism, which it is an alternative way of conceiving human history". This alternative "is based on breaking down the barriers between cultures". The third one refers to "a more integrative view of human community and human liberation" from separatist nationalism.

Imperialism relies on the large scope in the colonies. The colonies were affected by "a culture giving empire ideological attitudes" (222). Said believes that nationalism signifies all sorts of undifferentiated things, and identifies "the mobilizing force that coalesced into resistance against an alien and occupying empire on the part of peoples possessing a common history, religion, and language" (223). Nationalism was rooted in "the long-standing struggle for native rights and independence by Congress in India" (224).

"Cultural resistance to imperialism has often taken the form of what we can call nativism used as a private refuge" (275). "The hero of Algerian resistance, Emir Abdel Kader, in the nineteenth century" is an example for this resistance. Many postcolonial writers have employed the literary forms and techniques of the colonial power's own language, and so used allegory, disrupted narrative flow, magic realism, irony, and so on to create alternative views of the colonial situation. This appropriation demonstrates the ability of post-colonial writers to use the tools of metropolitan language against itself. These literary techniques are self-consciously used to demonstrate alternative and oppositional ideological principles. Roy exemplifies this appropriation in her Booker Prize- winning novel The God of Small Things. For example, Velutha is like Christ. He was a carpenter who suffered the little children to come unto him. Both, Christ and Velutha, were sacrificed for a greater cause. Christ was for the salvation of humanity, and Velutha wants to salvage the stratified social order and keeps an upper-caste family name intact. "Biblical Christian allusions help to show a constant and ironic parallel between what should be and what actually is" [17].

Said said that postcolonial writing-literary and theoretical-is a form of resistance to highly dubious Western construction of "Orient" in his foundational text of postcolonial criticism, Orientalism. Postcolonial literary studies focus on what happens when the formerly colonized culture starts to produce its own knowledge about itself. The discourses that create the colonizers as the knowers and the colonized as the subjects of knowledge all depend on our old friend, the structure of binary oppositions, including West/East, Occident/Orient, civilized/native, self/other, etc. when "the empire writes back", these binary oppositions are deconstructed; when a colonized subject insists on taking up the position of "self", as the creator of knowledge about his or her own culture, rather than as the subject of that knowledge, these binary oppositions start to fall apart. The present researcher believes that when Roy uses English language, she does a kind of resistance against colonization. Roy also employs a disjointed, nonsequential narrative that echoes the process of memory, especially the resurfacing of a previously suppressed, painful memory.

Roy rises from the level of personal and folk experience. She uses ancient figure such as, kathakali dance for a kind of resistance against British imperialism. Returning to the old principles represents their identity and it is a kind of resistance to colonialism. They want to show they have their identity themselves.

As the children attempt to form their own identities, naming and renaming themselves in the process, Roy places in parallel the effect of the process, by intertwining the past and the present. Similarly, this process echoes the progression of the Indian people, like all other cultures that attempt to find ways to maintain their traditions within a time of increasing globalization. The postcolonial writers try to form their identity by using the children's characters. The children use and repeat these phrases throughout the story so that the phrases themselves gain independence and new representational meanings in subsequent uses. Roy's most original contribution in this novel is her portrayal of children, entering into their thinking in a way which does not sentimentalize them but reveals the fierce passions and terrors which course through them and almost destroy them. 
Also the children imitate their adults and want to find independence. The postcolonial writers as well imitate the colonizers for forming their identities. Indeed, the perspectives of child protagonists Rahel and Estha are given the most weight of any throughout the novel. Even though Rahel and Estha are victims of circumstance, they are to an equal extent intelligent evaluators of it.

Although the book has no single protagonist and no definitive moral, it certainly champions details of life to which contemporary society tends to be too frenzied or farsighted to pay heed. Roy does her best in the novel (as well as in her other writing and political activism) to enfranchise the "Small Things", overlooked people and issues that, in her opinion, deserve more attention (232).

\section{Conclusion}

In conclusion, the present researcher tried to discuss some issues in TGST. These are outlined in separated items, such as the notion of hybridity, the role of women in Indian society, globalization, postcolonial resistance and Orientalism in TGST. The notion of hybridity is one of the items. The present researcher believes that this notion can be seen in several cases in the novel. Hybridity is a significant issue in the novel. Another issue is the role women in Indian society, because there are several female characters, such as Ammu, Rahel, and so on in TGST. Economic growth causes change in Ayemenem. It becomes a globalized community. Postcolonial resistance is an important issue in the novel. When Roy uses English language which it is a colonial language, she does a kind of resistance against colonization itself. Roy refers to the children's life as a means of resistance and may be seen as a kind of Orientalism in TGST. The results are given in a final item, the conclusion.

What is received in this novel is diaspora made in the different historical layers. And hybridity happens in the result of diaspora. And hybridity is dangerous, because two characters decline in the novel. And the future of India is in local, not globalization. Indian government should have political alternatives. Hybridity can be biological, cultural, linguistic or conceptual. Biological hybridity is such as Sophie Mol, and the twins. Cultural hybridity is such as Chacko. Linguistic hybridity is such as mixing Malayalam language with English language. The researcher believes that the twins have both biological hybridity and cultural hybridity. Hybridity has the capacity to challenge, subvert and oppose the structures of power. We can see this in children's behavior. They play with language to challenge a world order without a conscious intention. On the other hand, Velutha and Ammu continue their relationship consciously, and they want to be against the religious rules of Hinduism. The aim of a colonial educational system for Indians was a heterogeneous, hybrid entity, not a homogeneous, when they talked about persons "Indian in blood and colour, but English in taste". This statement, Indian blood and English taste, shows a hybridization. The colonizer introduced "elements of English literature and culture for the purposes of civilizing the native". There is a contradiction between civilized/barbaric and colonizer/colonized. This hybridity separates these educated Indians from other Indians but "they will never be pure". We can see this behaviour in Chacko's actions as an educated person in Oxford and an Indian man do according to caste system. Roy is going to show that hybridity is dangerous, because it is perceived as a subversive tool in relation to established hierarchies of language and culture.

\section{References}

[1] Anderson, Benedict. Imagined Communities. London and New York: Verso, 1983.

[2] Postcolonial Studies (The Key Concepts). New York: Routledge, 2007.

[3] The Postcolonial Studies Reader. New York: Routledge, 2006.

[4] Wisker, Gina. Key Concepts in Postcolonial Literature. London: Palgrave, 2007

[5] Said, Edward. Orientalism. London: Penguin Books, 2003.

[6] Tickell, Alex. Arundhati Roy's The God of Small Things. New York: Routledge, 2007.

[7] Bhabha, Homi K. Nation \& Narration. New York: Routledge, 2000.

[8] The Location of Culture. New York: Routledge, 1994.

[9] Benson, Eugene and L .W. Conolly. Encyclopedia of Postcolonial Literatures in English. New York: Routledge, 2005.

[10] Agustin Reyes, Torres, Roy's Inglish in The God of Small Things: A Language for Subversion, Reconciliation and Reassertion from https://www.researchgate.net/publication (1998)

[11] Tickell, Alex. Arundhati Roy's The God of Small Things. New York: Routledge, 2007.

[12] Tiffin, Chris and Alan Lawson. De-Scribing Empire. New York: Routledge, 2002.

[13] Waugh, Patricia. Literary Theory and Criticism. Oxford: Oxford University Press, 2006.

[14] Wisker, Gina. Key Concepts in Postcolonial Literature. London: Palgrave, 2007.

[15] Woodward Kath, Understanding Identity. Great Britain: Oxford University Press, 2002.

[16] Young J. C, Robert. Colonial Desire. New York: Routledge, 2005.

[17] Young, Robert. Postcolonialism. London: Blackwell Publishing Ltd., 2001. 